\title{
BETTY FREUND: A NURSE IN FRANCE - Part I
}

Compiled and edited by Betty Hugo*

\section{Introduction}

Betty Freund was the eldest child of John and Metha Freund (nee Menzel), both from Germany, who met in Philippolis, OFS, where they were married in the late 1870's. Betty was born in 1881. Then followed her sister Mimie (1883), and her brothers Freddy (1885) and Willy (1887). The family went to Germany a few years after Willy was born, settling in Glücksburg, Metha Freund's home town. The youngest child, Mina, was born there. By 1894 the Freunds had returned to Luckhoff where Metha's brother Wilhelm Menzel had been looking after their interests, but during the Anglo-Boer War the family moved to Cape Town where they lived, first, in Livingston Villa in Cecil Street, Claremont, and subsequently in Lansdown Road, also in Claremont, in a house called Zürenborg. The children had been to school in Luckhoff and Glücksburg; Freddy and Willy matriculated at the Rondebosch Boy's High School, Betty and Mimie at Bloemhof Girl's High School in Stellenbosch, and Mina in Edinburg, Scotland, after having attended Milburn House in Cape Town.

Betty remained in Stellenbosch after matriculating to take a course in what was called "home industry", residing at Greylock, the home of the Jannasch family, for the duration of this course. She then went to Luckhoff, where the family was living by this time (1903). She stayed at home to help her mother, as unmarried daughters did at the time, but had numerous trips abroud visiting relatives in Germany and elsewhere, as her collection of postcards indicates. Her nursing career began in 1912.

Her contract with the Johannesburg General Hospital was dated 4 December 1912 to 4 December 1915 . Her salary was $£ 25$ p.a. for the first two years, and $£ 42$ p.a. for the last year (board, lodging, laundry and medical care were included).

When the First World War broke out in 1914, Betty joined the Ambulance Süd-Africaine, which left Cape Town in November 1914 and was eventually stationed at the Beau Rivage Hôpital in Cannes, France, for the duration of the war. This venture was headed by $\mathrm{Dr}$ G.A. Casalis, a well known surgeon of French extraction, who was associated with the Mount Royal Nursing Home in Claremont, where Betty's mother had undergone a mastectomy performed by him, and where Betty herself had met him, presumably when she visited her mother in hospital. Dr Casalis, at the last meeting of the Cercle Francais, a cultural organisation founded by Casalis himself, proposed that the Cape Province equip and support an ambulance unit in France. He invited Betty to join this unit. Betty's mother had by this time sufficiently recovered from her operation and, since everyone believed that the war would not last more than six months, Betty was persuaded to accept the invitation. The Johannesburg Hospital Board must have released her from her contract or allowed her to transfer her services to the ambulance. In any event, she had not yet qualified when she left Johannesburg. She was then thirty-three years old.

She died in France shortly before the end of the war in 1918 at the age of thirty-seven. According to the official documents her age in 1918 was thirty-one. This is inaccurate. She was over the age-limit specified for acceptance in the Johannesburg General Hospital in 1912. How she managed to be accepted remains a matter of conjecture. It is possible that the figures 1 and 7 were confused (1881 or 1887 as her date of birth) or that Betty, because she was unmarried, took advantage of this confusion, since it made her six years younger and enabled her to pursue a career in which she obviously found her vocation. All the official reports speak of her ability, conscientiousness and generosity. She was posthumously awarded the Médaille d'or des Epidémies by the French Government and given a military funeral in Cannes. Her name, together with the names of 18 other "Sisters of the Empire" who gave their lives in the Great War, appears on the Oak Screen adjacent to the famous Five Sisters Window in York Minster.

Betty's story is not unique or heroic. Her letters are ordinary letters, the kind any daughter would write to a mother. She died of cancer about six months before the end of the war. Her mother kept her letters for sixteen years, expressing the desire to have them buried with her when she 
herself died. But the letters were "rescued" by a grand-daughter who was old enough at the time to realise that they could one day be of interest to the family - and possibly to other South Africans to whom details of the past mean something.

I myself read these letters for the first time about seven years ago ( 1 am the youngest granddaughter, Betty Freund's youngest niece) and I found them very moving, very sad, although they concerned the life of an aunt I had never known, an aunt who died thirteen years before I was born and whose name had been given to me. Betty Freund must have known she was dying as a nurse, how could she not have known? - yet her letters towards the end remain reassuring and speak of her concern for others throughout. It was this quality of selflessness that I admired most in her letters.
A paradox of Betty's career in France during the war is her German background: as a South African she joined a unit that went to France to nurse soldiers who has been wounded in combat against the Germans. Clearly her decision to join the Ambulance Süd-Africaine had nothing to do with nationality or political persuasion. She simply wished to serve where her services were most needed.

She was not an Edith Cavell but, like thousands of others, she made a contribution during the Great War that meant a great deal to the soldiers she nursed. We have a duty to record and to remember, and I am sure that now, half a century after my grandmother's death, even she would have understood and approved the publication of her daughter's letters, expecially as they are a tribute to Betty in particular and to the Nursing Profession in general.

\section{Family Background}

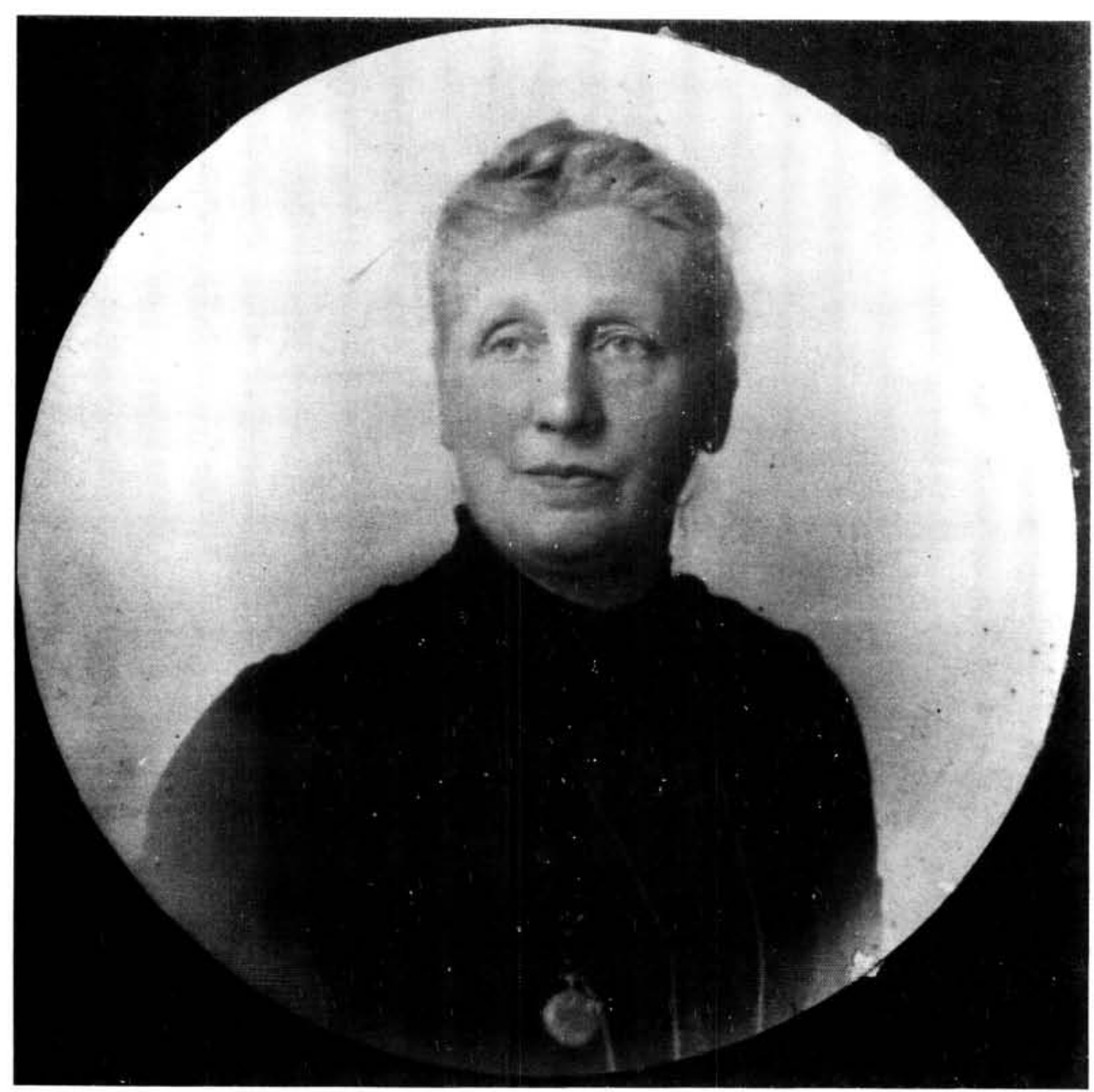

Metha Freund 


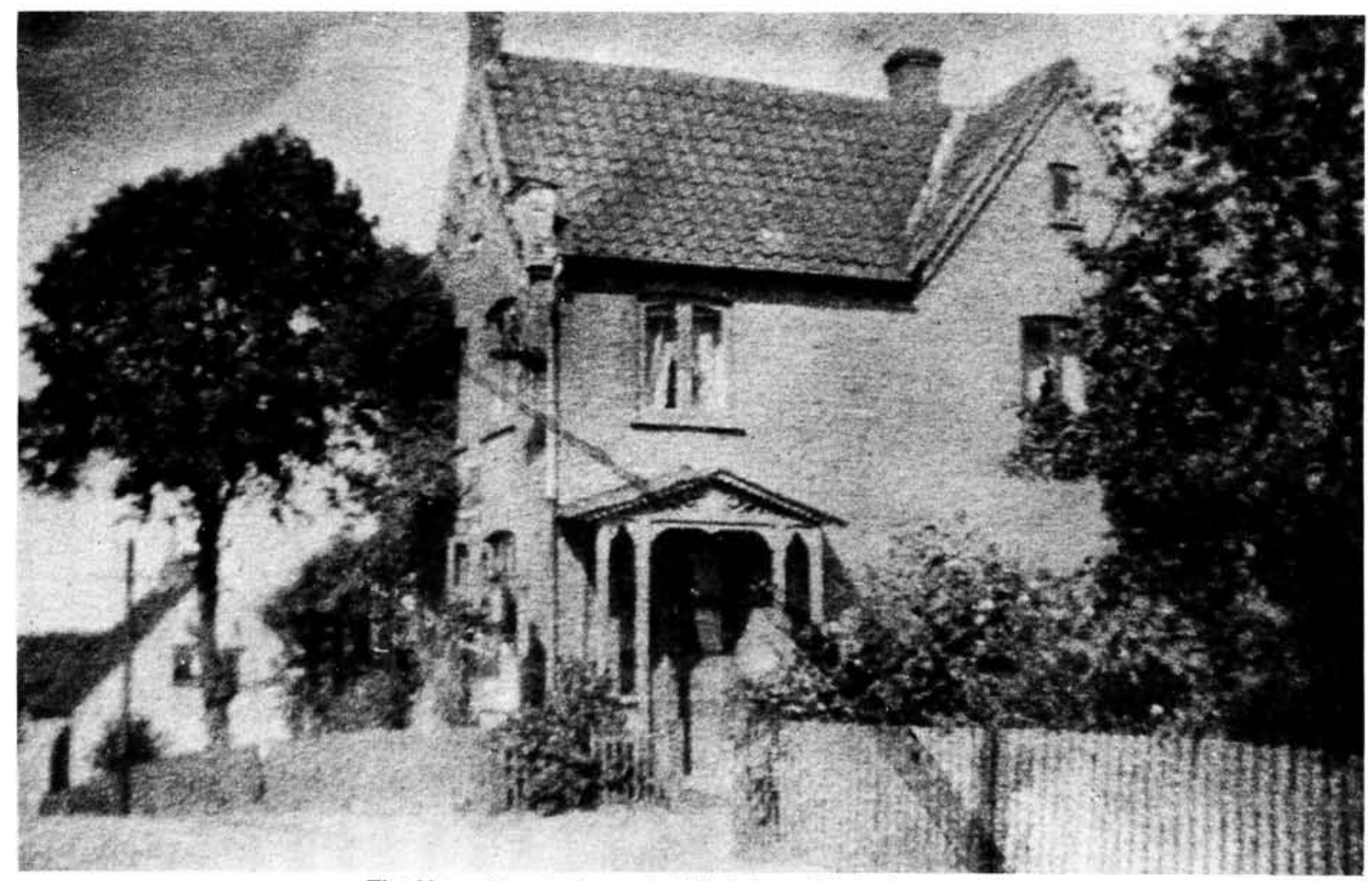

The Menzel family home in Glücksburg (Metha's parents)

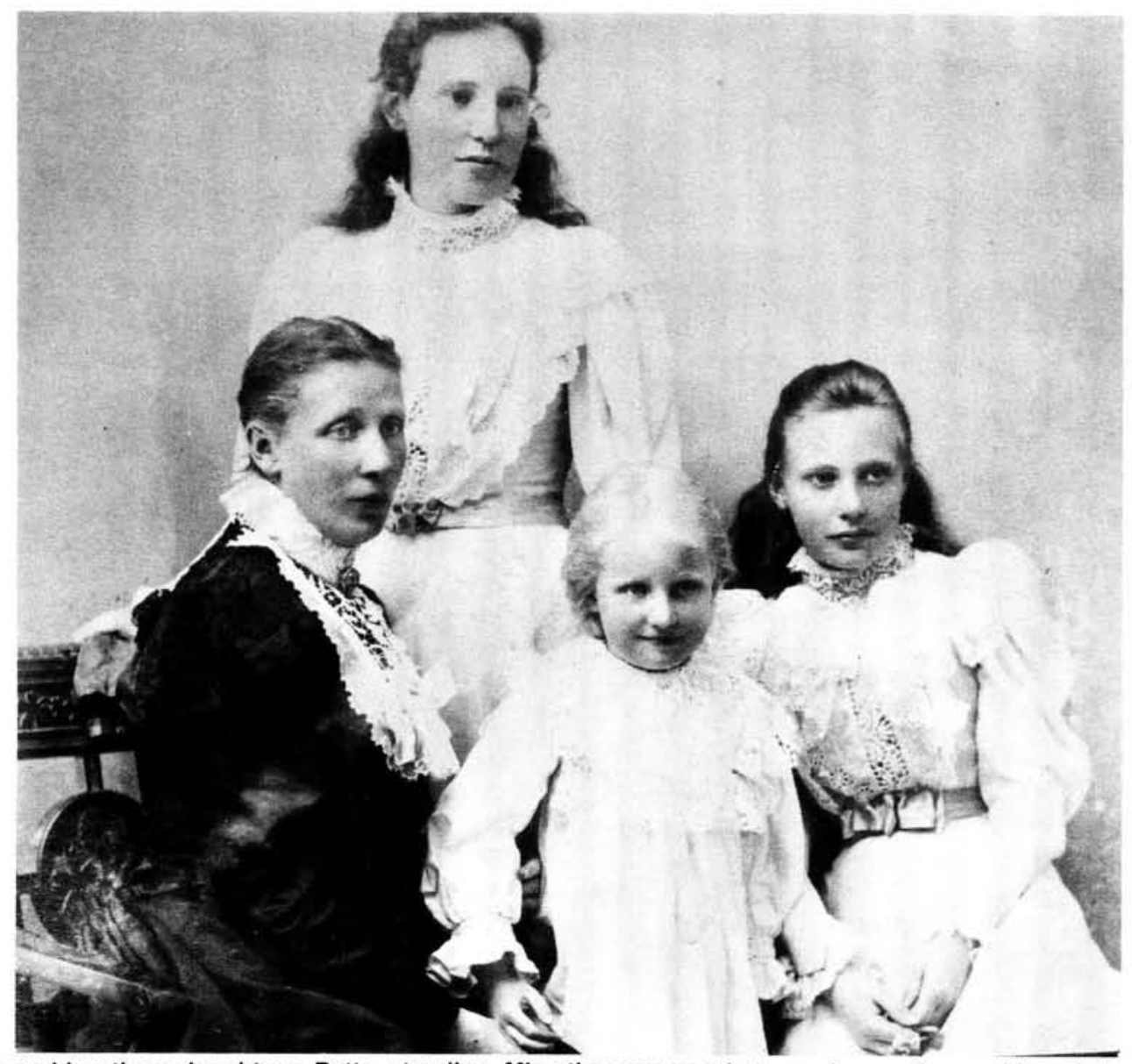

Metha and her three daughters: Betty, standing, Mina the youngest between her mother and her sister Mimie 


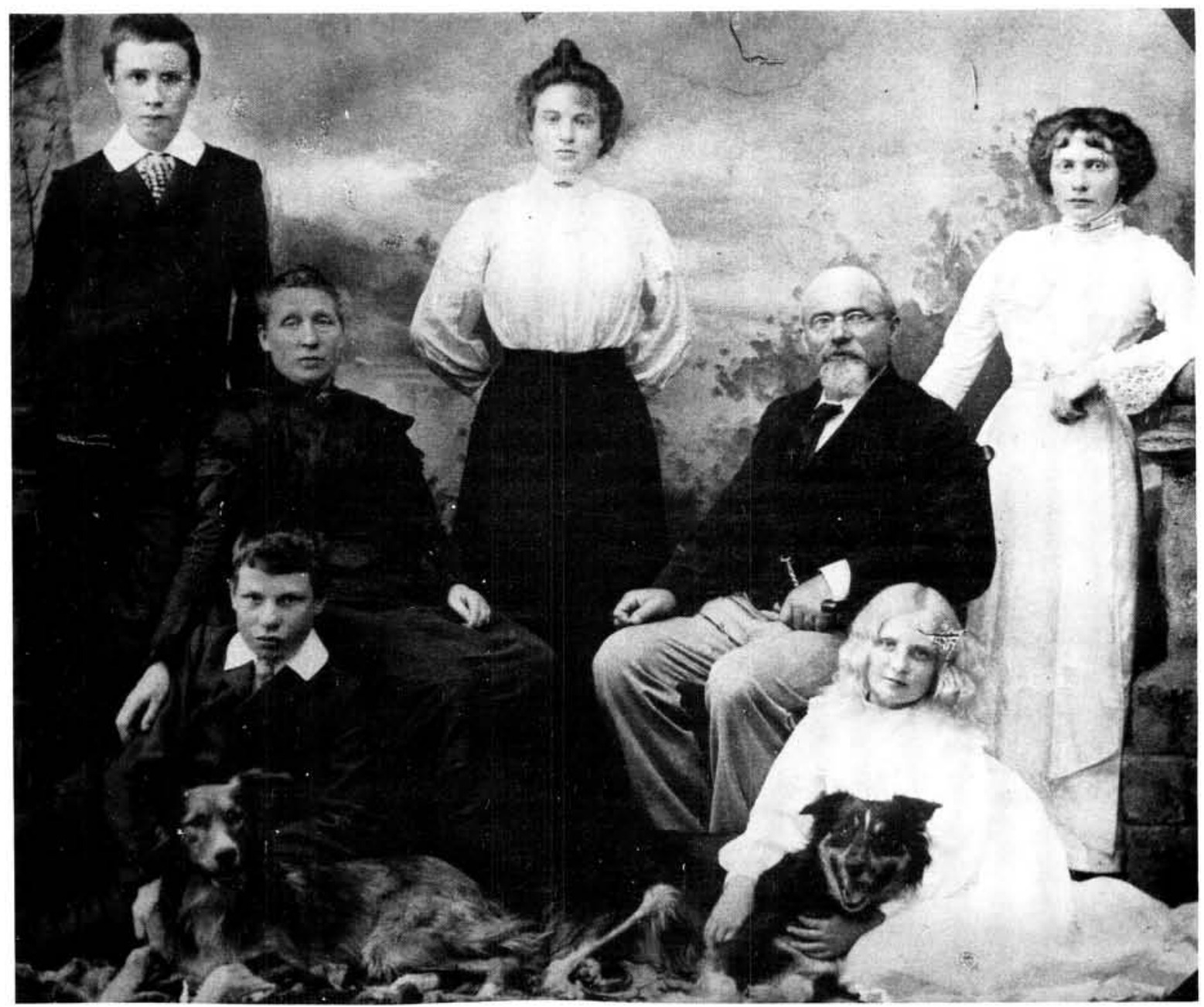

The Freunds in Glücksburg. Standing, from left to right, Freddy, Betty and Mimie; Metha and John seated, with Willy and Mina sitting on the floor

John Freund was born in 1855 in Schlüchtern, near Frankfurt-Am-Main, Germany. He emigrated to South Africa at the age of about twenty and settled in Philippolis in the Free State where he had a job as a clerk in a shop. His brother had emigrated to America and John's second daughter, Mimie, was to correspond with her American cousins for quite a number of years before the families eventually lost touch with each other. There were also some other German cousins in South West Africa, whilst yet other members of the Freund family settled in Australia. It was at Philippolis that John met Metha Menzel and married her.

Metha Menzel was born in 1853 in Glücksburg, near the Flensburg fjord which was to become the focal point of a German-Danish controversy about boundaries in 1900. Metha came to South Africa with the Sem family, evidently to help with the Sem children on board ship. Her parents were Friedrich Ludwig Casper Menzel (18231901) and Marie Josephine Menzel, born Weber (1830-1901).
John and Metha were married on the farm Otterspoort in the district of Philippolis. Betty and Mimie were born in Philippolis, Freddy on the farm Jonasfontein where the family had their first shop, and Willy on the farm Tevredenheid, now Orangia, where the family also had to shop. Tevredenheid is in the Luckhoff district. A few years after Willy was born the Freunds returned to Germany, leaving their farm and other possessions in the care of Metha's brother, Wilhelm Menzel, who had also come to South Africa. Wilhelm Menzel died in Luckhoff in 1917 and was buried in the cemetary there. The youngest child, Mina, was born in Germany (in Schleswig-Holstein, near Glücksburg) in 1891.

When the Freunds left Luckhoff they had already become settled members of the community: they owned property, they were well known, and they obviously intended coming back. There is an amusing story about their departure at the time: the family boarded the train for Cape Town at Witput Station, asking the engine driver, a friend of theirs, to stop at a certain point in the veld to enable 
them to say good-bye to another friend, Mr Drost, who lived close to the railway-line. The engine driver obliged.

The Freunds were back in Luckhoff by 1894 , at which time John Freund purchased Erf No. 136 in Luckhoff, and it was on this erf that he built a house that resembled the Menzel family home in Glücksburg. According to the Deed of Transfer John Freund paid $£ 10$ for the erf. The house is still there, on the southern corner of Voortrekker and Rabie Streets, and now belongs to the Bouwer family whose daughter is married to John Freund's grandson. During the years 1934 and 1954 the house belonged to a family by the name of Fowler, but John Freund Jnr bought the property back in 1954 and then sold it to the Bouwers.

The Freunds also had interests in Cape Town. They first had a house in Cecil Street, Claremont (Livingstone Villa), and later a house called Zürenborg in Lansdown Road, also in Claremont. They lived in Claremont during the Anglo-Boer War and when the children were at High School. Freddy and Willy went to Rondebosch High School, where, some sixty-five years later, their sister Mimie's great-grandsons, Chris and Peter Roux, were to matriculate. Betty and Mimie went to Bloemhof Girl's High in Stellenbosch, where, fifty years later, their sister Mina's children, Kina and Betty Botha, were to matriculate. Mina herself went to Milburn House, a double-storeyed thatched house that was used as a school build- ing by Miss Kate K. Gale, one of the first woman graduates in England, for her special school for "young ladies from good homes". The house stood where the Claremont Civic Centre is today. Milburn House closed in the early 'thirties and burned down shortly afterwards. The estate had originally belonged to a Mr Leader who built the house and then sold it to Hugh Donan in 1894, the year Miss Gale opened her school. Hugh Donan sold the property to Miss Gale and Miss Augusta Lilia in 1903.

Freddy and Willy returned to Luckhoff and became farmers; Betty and Mimie remained in Stellenbosch, Betty to take up "home industry" and Mimie to study music. Mimie obtained her Music Certificate under the University of the Cape of Good Hope, forerunner or the present-day University of South Africa. Mina matriculated in Edinburgh, Scotland, and then went to London to train at Elsie Fogerty's School of Elocution. While there, she met and befriended Sybil Thorndike and Lewis Casson. She also appeared at the Albert Hall and the Lyceum Theatre together with F.R. Benson, Lena Ashwell, Sir Herbert Beerbohm Tree and others. She retured to Cape Town to accept an appointment as Teacher of Elocution at the South African College of Music, the Good Hope Seminary, St Cyprian's, Wynberg Girls' High School, and the Ellerslie School for Girls. When Professor Bell (affectionately called "Daddy Bell") presented his first play, Everyman,

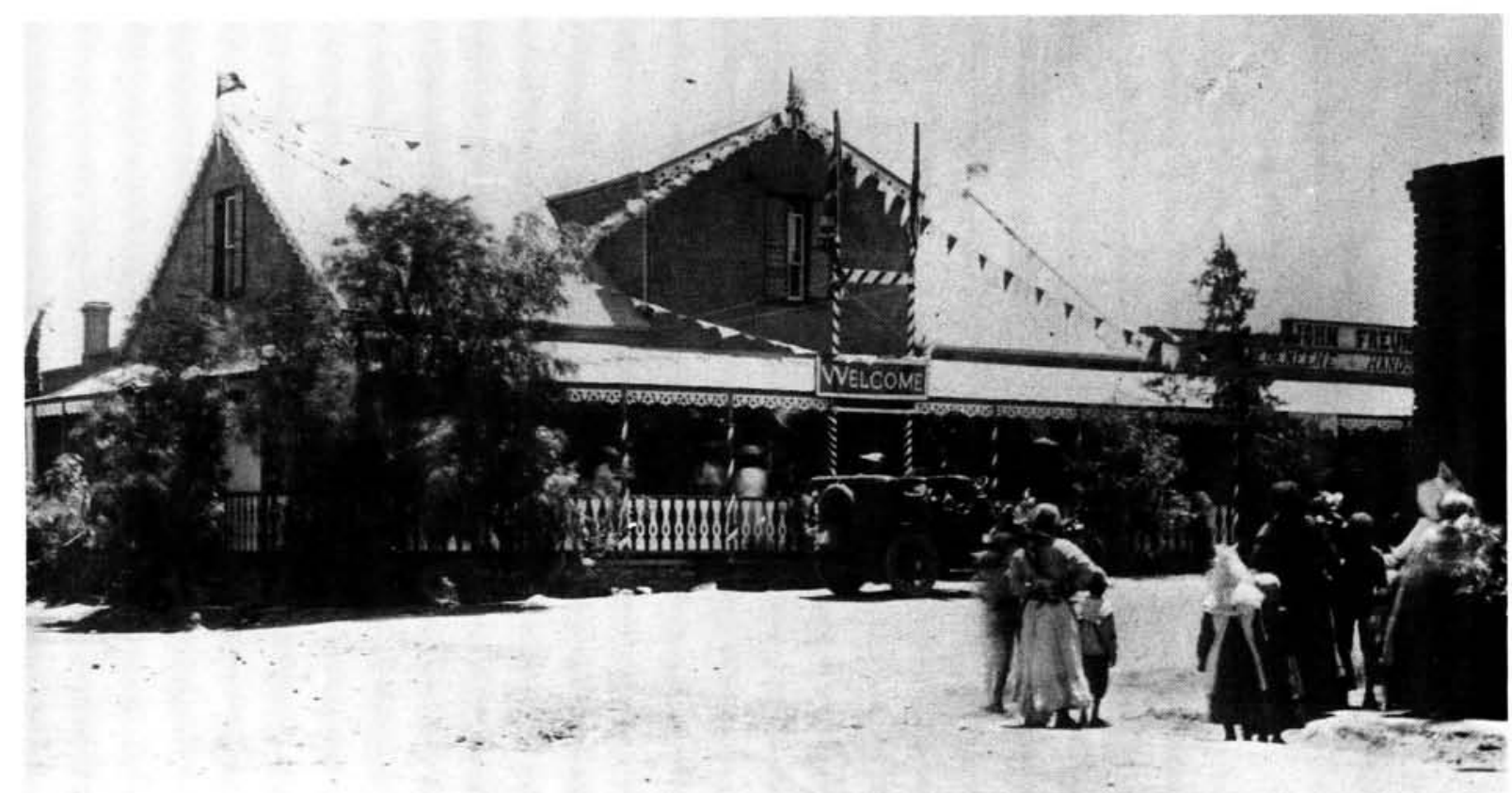

The Freund home after the Anglo-Boer War. This photograph was taken at the time of the opening of the Luckhoff Water Works: Sir Hamilton Goold-Adams - one of Lord Milner's Lieutenant-Governors - came to Luckhoff for the occasion. John Freund was then Mayor of Luckhoff. Lord Milner at the time was Governor of the Transvaal and the Orange Free State. 
in the Stal Plein Hotel, home of the College of Music at the time. This company of "dining room players" then moved to the Hiddingh Hall, and later to the now famous Little Theatre, still the centre for students of Drama at UCT. Mina Freund married Chris Botha in 1927 and moved to Bloemfontein. Chris was to become Judge President of the Orange Free State. It was on their farm Linden that Sybil Thorndike and Lewis Casson visited them in the 'thirties during one of their concert tours of South Africa (Sybil Thorndike was godmother to one of Mina's daughters).

Mimie married Freddy Mudd, an Englishman, whom she met when she returned to Luckhoff after completing her training in Stellenbosch. Freddy Mudd came to South Africa as a member of the Boy Scout Unit under Baden-Powell during the Anglo-Boer War. After the war, he joined the South African Constabulary and was posted to Luckhoff as Justice of the Peace. He and Mimie settled on the farm Visser's Drift in the Luckhoff district. Their daughters, May and Lou, were born in Luckhoff. May married Chris Roux, who was born at Mostert's Drift, Stellenbosch, where the couple now live after having spent a life-time building up a Thoroughbred Stud at Ramah, Witput, in the Karroo. Chris Roux's mother was the widow of Abraham Marais when she married Chris's father, Piet Roux. Abraham Marais was the brother of Jannie Marais of Coetzenburg, one of the original benefactors of the University of Stellenbosch. May and Chris's son, Pietie, now lives at Ramah with his wife Jean; their daughter, Elizabeth, is the only member of the family who followed her great-aunt's footsteps and chose nursing as a career. Lou married Jack Lotter and they had one son, Leon, who lives in Bloemfontein with his wife and baby son. Jack Lotter died in 1974, and Lou in 1983.

Betty Freund's brothers, Freddy and Willy, married in 1922 and 1919 respectively. Willy married Rose $\mathrm{Nel}$ and they had three children, two sons and a daughter. Rose Freund, now ninety-two years old, still owns a house in Luckhoff, although she lives in Pretoria with her daughter and son-in-law. Her two sons, John and Reuel, like their father and grandfather, have had terms of office as Mayor of Luckhoff and are very much at the centre of local affairs. Reuel and his wife Ria and their five children still live in Luckhoff; John and his wife Joan now live at Van der Kloof Dam which, largely through John's endeavours, is rapidly becoming a popular inland holiday resort. They also have five children. Willy and Rose's daughter, Joyce, is married to Gert Otto, also from Luckhoff. Joyce taught at the Luckhoff school for many years before her marriage to Gert Otto. Freddy Freund married Maria Theron and they had two children: Daphne, married to Ralph Nicholson, and Tom, who was unmarried and farmed on Klein Palmietfontein, the family farm, until his death in 1984. Daphne died in Johannesburg in 1973.

The Freunds have been synonymous with Luckhoff for four generations. The old couple, John and Metha, were extremely well known and well liked. John's nickname was "Mr Friend" ("Freund" in German means "friend") and their home was described as a "home for everyone away from home" in a newspaper article which appeared at the time of John's death (The Friend, August 1928). Today, a hundred years later, two grandsons, two great-grandsons, and two great-greatgrandsons are still there, all farming within a radius of about 50 kilometres of Luckhoff. Their descendants today are forty-five in number.

Metha survived her daughter Betty who died in France in 1918; her daughter Mimie who died in 1921; and her husband who died in 1928. She herself died in 1934. Her daughter Mina died in 1938, and her sons Willy and Freddy in 1949 and 1963 respectively. The entire family died of cancer, except Metha herself who died of heart failure at the age of 81 . Of the nine grandchildren born between the years 1909 and 1932 four have died of cancer: Kina in 1976 at the age of 37, Daphne in 1973 at the age of 48 , Lou in 1983 at the age of 72, and Tom in 1984 at his 56th birthday.

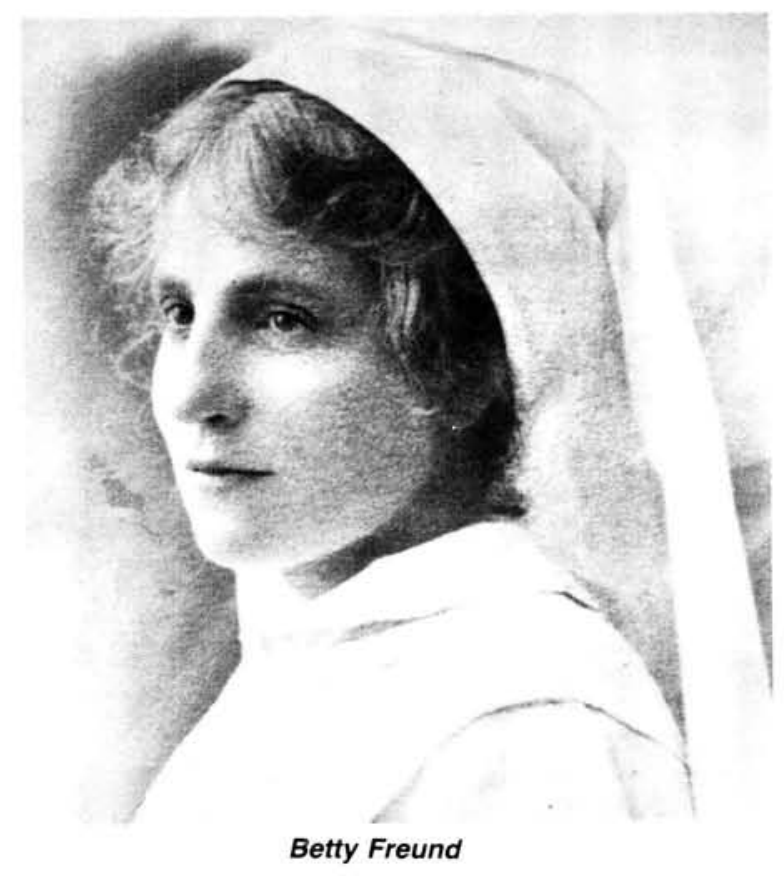




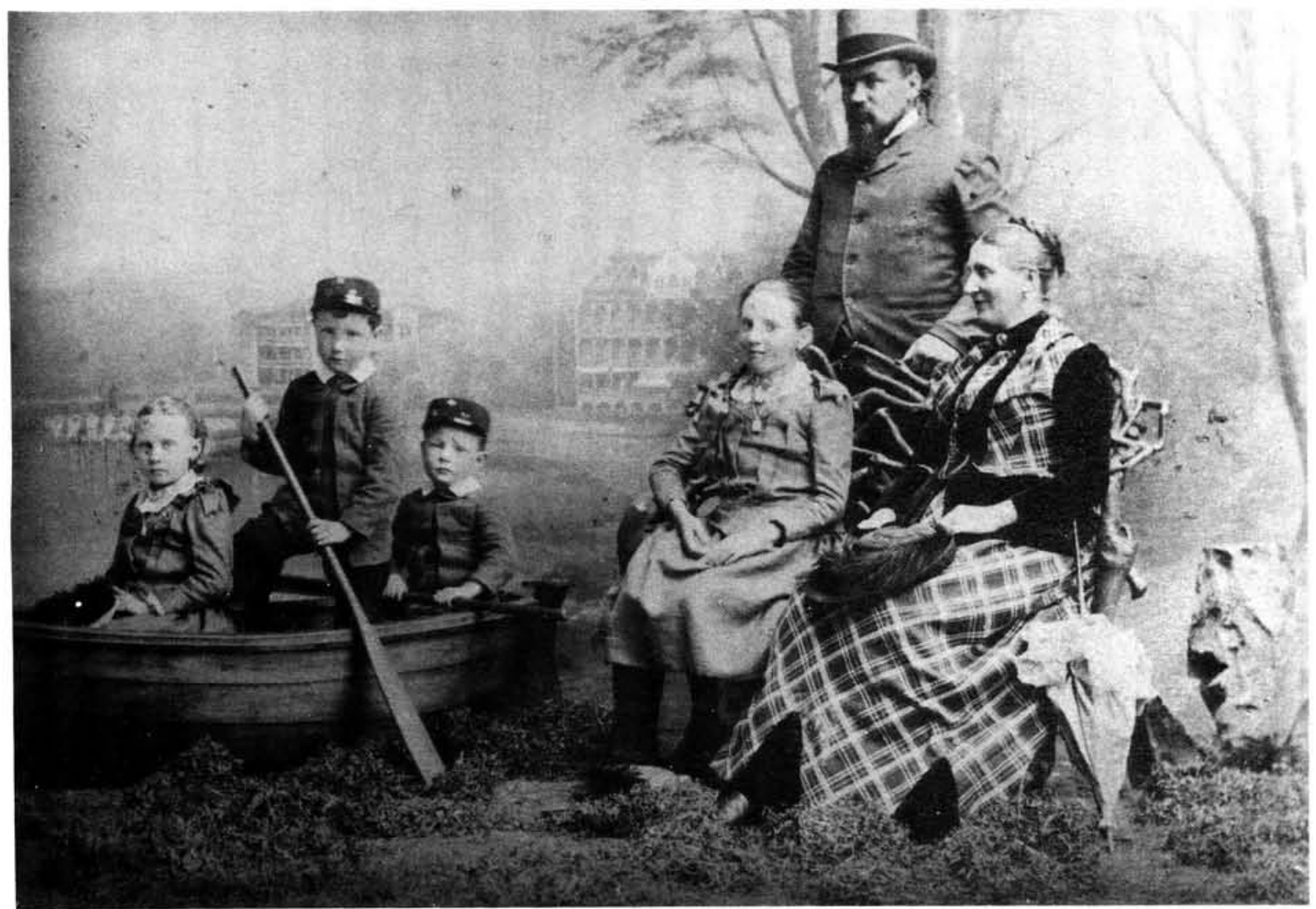

The Freunds in Glücksburg before Mina was born. Mimie, Freddy, Willy in the "boat", Betty next to her mother, John Freund behind them. An amusing detail is worth mentioning here: photographers used to "clamp" people's heads to cope with exposure-times and one can be certain the kiddies in the "boat" had been well and truly "clamped" for this one!

\section{ELIZABETH FREUND (1881-1918)}

\section{The historical perspective: An outsider's view, by Janice Farquharson}

During the First World War thousands of men and women who were caught up, willingly or otherwise, in some form of active service recorded their experiences in diaries and letters home. There has never been a war more fully chronicled: literacy was the norm not the exception, people from all walks of life and from all parts of the world were involved and, above all, the war was largely static. The Second World War was one of movement so there was often no time or opportunity to settle down to a steady correspondence and posts were often irregular, but for four years from 1914 to 1918 the Western Front remained virtually unchanged. Letters crossed the channel regularly and it was commonplace for a letter posted in London before noon to be delivered to Battalion Headquarters and sometimes into the forward trenches - within thirty-six hours.

Many of the diarists and regular letter-writers were intelligent and articulate; the automatic tele- phone and direct dialling - those implacable enemies of literate expression - were toys of the future. If the soldier, or the nurse, or the VAD, or the airman wished to communicate, he had to write.

Some of the diaries and letters were the basis of the truly great biographies and semi-biographical writings of the nineteen-twenties. Graves's Goodbye to All That; Sassoon's Memoirs of a Fox-Hunting Man and its companion columes Memoirs of an Infantry Officer and Sherston's Progress; Edmund Blunden's luminous Undertones of War are fundamental to an understanding of the First World War and from them most of the modern conceptions of that war have sprung.

Most wartime diaries, however, did not have so distinguished a career; they were probably lost in action, or forgotten, or simply thrown away. Letters, once read, were discarded or - if kept at all - were simply regarded as curiosities. I venture to guess that most families, expecially those that have remained more or less in the same district or small town, or house, have boxes or suitcases of letters mouldering away in some box room. (My grandmother left mountains of albums with 
photographs of the Boer War, and soup tickets from the siege of Kimberley; and my beloved magpie mother hoarded hat-boxes of letters, postcards, and "snaps", including one of a young man in the Royal Flying Corps who was shot down two days before the Armistice).

Anyone fortunate enough to do research in the archives of the Imperial War Museum in London will have first-hand acquaintance with the endless shelves of red boxes in which are stored the diaries, letters, and ephemera donated to our collected by the Museum, each box a treasure trove of information about the Great War.

One comes to the inevitable question: is this modest collection of Elizabeth Freund's letters, written by a nurse from an obscure Free State village, who served in an unimportant hospital a considerable distance from any front-line or wartorn region of any interest to anyone outside the immediate family? Are Elizabeth Freund's experiences worth recalling from obscurity, other than as an act of pietas by a niece born long after she herself was dead?

I think the outsider must answer that these letters are of value on three levels:

First, they are the record of a loving, if anxious, relationship between mother and daughter; second, they are the self-portrait of a very brave and compassionate woman; third, they add a dimension, however slight, to our knowledge of the war.

This does not imply that I have the slightest intention of over-estimating the importance of these letters; they are not particularly well written and one can detect a direct translation from German into English at times; they are not always very interesting and she skimps on detail, but their very ordinariness makes them interesting. She is not writing for a wider audience than her mother or her family can provide and therefore she is not self-conscious. Censorship inhibited her as it inhibited everyone else. In a letter of July 1917 she refers to the Military Authorities who did not like some of the remarks one of the sisters in the hospitals had made in a letter: "They are getting very strict now and they are quite right... Family matter are the only subjects one should write about these days ...."

Betty Freund will not tell the reader anything new about the war her letters are full of a sense of the immediacy of the war itself. When she arrives in London she is full of details of that city in war- time, the cold, and the people busy with their Christmas shopping, "heaps of people in black ... London in darkness ... You can't help admiring the English taking everything very calmly". The details are irresistible; she mentions the London buses which are in France transporting the troops (the IWM has numerous photographs of the same buses, in drab khaki, on the road to Ypres; one of them is now on permanent display in the museum - it was driven into the Museum yard some six years ago by an Old Soldier who had driven it in Flanders in 1914). Betty notes that "heaps" of men have gone to the war and one of the signs of wartime austerity is that the post is "only delivered 4 times a day instead of 6 , the milk only comes round twice a day instead of three times ..." (This is a lost world in more senses than one!)

She mentions the other South Africans in London: "Miss Schreiner, the High Commissioner's daughter". More than two years later another South African, Denys Reitz, had also come to England to enlist in the British Army. He also called on the Schreiners, who were his uncle and aunt, and later made the remark that he "felt no more of a stranger in London than in Cape Town or Johannesburg ..." (Trekking On, p.161).

One very interesting facet of the letters is her comparative isolation from outside news. She asks for details of the Rebellion of 1914, that unfortunate episode in South African history which split the Afrikaner community and brought brother out against brother. At the time she was asking for news the London Times was providing full accounts of the progress and ultimate failure of the attempt to link up with the German forces in South West Africa and thus restore a republican hegemony. Her queries show that she had not yet learnt her way around, it seems never to have occurred to her to refer to any London newspaper.

She arrived in Cannes in mid-January 1915 where she would spend all her nursing service. Throughout the following three years two themes become clear: she was not well, her health was deteriorating and she was compelled to hide the truth from her mother. There is something deeply moving in her persistent cheerfulness in the letters home. The outsider must wonder if her burden would not have been lighter if she could have confided in her mother. Here again she was essentially of her time. Most women were expected to stay at home and it required considerable initiative for any woman to break away from 
established custom; Betty Freund would certainly not seek to add to her mother's natural anxieties. (Vera Brittain, who as a VAD had nursed in London, Malta, and at Etaples was ordered home by her parents at the height of the fighting in March 1918 when the Germans seemed likely to break through to the Channel ports. Her mother was in a "nervous state" and needed Vera to "help" at home. Vera obeyed).

Betty Freund seemed obliged to minimise her illness: she would be home "next Xmas", or when it was safe to travel (an indirect reference to the dangers of submarine warfare).

The other theme, unselfconsciously heroic, is her concern for the men she was nursing and the satisfying awareness that, although she was not really in a front-line hospital, she was doing good work.

In October 1916 she had a "lump" removed and wrote home that she was well and would "want to go on with my nursing a little longer if you are all well at home. I could not come back and sit in Luckhoff and do nothing, it would worry me so much". Her health was failing but she refused to give up: "Life is terribly sad and hard for everybody these days ... I came back to hospital two days ago and I am pleased to be back, the soldiers were all so pleased to see me again ...."

The concern for an identification with her patients did not falter and the letter of 9 March 1918, two months before her death, was really an apologia pro vita suae: " ... when I think I'll have to give up nursing I almost can't bear the thought of it all. In Luckhoff there is nothing for me to do ... One is only really happy when you work and you do something for others in Life".

In 1916 the hospital helped nurse some of the Russian wounded who had been fighting with the Allies in the Balkans, the "forgotten" campaign in Salonika, and the staff were "expecting wounded after heavy fighting they have had in the north." She was referring to the battle of Verdun, where slaughter had just begun - French casualties would eventually total more than 700000 in some seven months.

She wrote on 29 July that the "town is full of wounded from Verdun", then follows a casual remark: "I see in to-night's papers that the South Africans have done some heavy fighting and that there is a long list of casualties." This was the encounter at Delville Wood, which has since be- come the ultimate battle for South African Forces, as Gallipoli is for the Australians and New Zealanders, and Vimy Ridge for the Canadians.

If there is any passage in the letters which is of lasting interest and merit it must be her descriptions of the troop trains passing through Cannes on their way to the Italian Front (description follows later on in the article).

The same reaction was voiced by Vera Brittain who was at a military hospital near Etaples in 1917 and 1918, past which the trains ran from Boulogne to Paris, and by Winifred Holtby who served as a twenty-year-old in the Women's Auxiliary Army Corps at Cannes in 1918. (Winifred Holtby's poem is quoted later on in the article).

The feelings of these three women, who were so widely different in nature and experience and renown, are perhaps the best proof that the war could give rise to a universal emotion of profound compassion.

Betty Freund died in harness. She had obviously been gravely ill for months, but perhaps hers was not so untimely a death after all: she died doing "something for others in life". Her letters are not important but they are part of the human experience in those extraordinary years.

Are they still of interest?

Homo sum; humani nil a me alienum puto- I am human; I count nothing human indifferent to me.

A poet who lost his only son in the Great War had remembered the nursing sisters who had served in the Boer War. Perhaps his words can speak for Betty Freund and the host of others who sought and found fulfilment in helping others:

When the days were torment and the nights were clouded terror,

When the Powers of Darkness had dominion on our soul -

When we fled consuming through the Seven Hells of Fever,

These put out their hands and healed and made us whole.

Till the pain was merciful and stunned us into silence -

When each nerve cried out on God that made the misused clay; 
When the Body triumphed and the last poor shame departed -

These abode our agonies and wiped the sweat away.

Bold behind the battle, in the open camp all-hallowed,

Patient, wise, and mirthful in the ringed and reeking town,

These endured unresting till they rested from their labours -

Little wasted bodies, ah, so light to lower down!

Whereof we they ransomed, while the breath is in our nostrils,

Now and not hereafter - ere the meaner years go by -

Praise with love and worship many honourable women,

Those that gave their lives for us when we were like to die!

\section{(Excerpt from Rudyard Kipling's The Dirge} of the Dead Sisters)

\section{George Arnold Casalis}

George Arnold Casalis was born in 1865. His background was one of missionary work and medicine, in almost equal proportions.

His father was Eugene Casalis, son of one of the original French trio of missionaries that worked closely with Moshesh, and his mother was Sarah Dyke, daughter of a missionary (other family names associated with this mission station are Mabille, Pellissier, and Rolland). Eugene was sent from Basutoland (now Lesotho) to France to be educated there - he was, in fact, one of the first of the missionaries' children to be sent to France for his education. Eugene qualified in Paris in 1862, returned to South Africa and practised first in Hermon (near Mafikeng) and later in Morija. During the Gun War (1880-1881) Eugene was given the nickname "Thipa ea Letsie" (Letsie's Knife) on account of his skilful surgery. He worked with tremendous zeal and devotion and was evidently more missionary than medico.

George Arnold Casalis was a dedicated man. He was also a difficult man: quick-tempered, impulsive, yet equally quick to resume his usual kindly manner when the cause of his anger had been removed. The portrait of him that emerges from Betty Freund's letters is the portrait of a man who knew exactly what he wanted: to serve the country of his origin by means of his skill as a surgeon. To all those who helped him promote this goal he remained loyal throughout.

George Casalis (later Casalis de Pury) qualified in Edinburgh in 1887 (M.B., C.M.) and obtained his M.D. much later in 1922. He was one of the first medical men in South Africa to specialise in a particular part of the human body. He worked first in Basutoland, then in Port Elizabeth, and then settled in Cape Town as an "abdomino-gynaecologist". In Cape Town he was also Head of the Mount Royal Nursing Home in Claremont, and it was at this hospital that Metha Freund, Betty's mother, underwent an operation performed by $\mathrm{Dr}$ Casalis. This was in 1913.

When the Great War broke out in 1914, Dr Casalis immediately began to organise the Ambulance Sud-Africaine without a backward glance, it seems, to any regrets he might have had at leaving his practice in Cape Town. It was at a meeting of the Cercle Francais - a cultural organisation for French speaking Capetonians and students of French - that Dr Casalis proposed that the Cape Province be approached to support this venture.

The Ambulance Sud-Africaine was a success, thanks almost entirely to Dr Casalis's unflagging energy and devotion. Dr Casalis's use of sun treatment for wounds was conspicuously successful at Beau Rivage in Cannes during the Great War. In 1918 he was awarded the Croix de la Legion d'Honneur and received the grateful thanks of the French Military Authorities.

He remained in Cannes after the war, and died there in April 1931.

Dr Casalis and his wife represented Betty's parents at her funeral in Cannes, and the following letters from them to Metha Freund show that they regarded her "as dear to us as our own child":

\section{Dr. Casalis' Letter}

Cannes, May 8th, 1918

Dear Mrs. Freund,

By the time you receive this letter you will have already heard weeks ago of the death of poor dear Betty. I have requested our Secretary in London to let you have as many details per cable as possible, so that you should not have waited too long to get fuller news. To-day I send enclosed a full report of the circumstances attend- 
ing her death and the burial she received in Cannes.

I cannot say what we all feel about the sad loss we have experienced, except that Betty was as dear to us as our own child and we feel her death as keenly.

I trust the honours that have been bestowed on her memory will paliate in a measure, the sence of the loss you have experienced, for which I cannot express too much. To you and your whole family our deepest sympathy.

With kindest regards,

Believe me always yours very sincerly,

\section{G.A. Casalis}

\section{Mrs. Casalis' Letter}

Cannes, May 10th, 1918

Dear Mrs. Freund,

You must know by this time of the great loss of your dear daughter Betty, a loss we share with you from the bottom of our hearts. I have but little to add to the full reports that will be sent you. Our hearts are still so full that I don't know how to expres to you all we feel.

I expect you will have read the letters my husband and I wrote to your daughter Minna. We addressed them to her not knowing how much you were prepared for such sad news.

In all your sad grief there will be some consolation for you to know that Betty never realised how ill she was and never knew the end was so near. She did not suffer much except at times when her breathing was a little difficult, then we relieved her with injections. She passed peacefully away in the night of the 3rd and 4th of May, at 2 o'clock. Dr. Baily and myself were with her, as well as Sister Archer Isaac, Miss Topham her great friend. Mrs. Wentz also nursed her during the day and Sister Knowles. Every possible thing was done to make her last moments easier. She died like a brave soldier at her post of honour.

I was very distressed that the medals from the
French Government, we had been writing about for months, had not come in time, knowing how she dearly wished for it. I sent a wire to the War Office advising them of the day of the funeral, and the official answer from the Ministery arrived just in time for the ceremony. This also will be a small compensation to know that dear Betty's grand work has been recognised by the French Government, and that she has been awarded the highest distinction.

As soon as the medal itself arrives we will forward it to you through the High Commissioner in London, Mr. Schreiner.

As to her belongings, clothes, etc., everything has already been carefully packed by myself, Sister Archer and Miss Topham and we are waiting to know the instructions to send them to you. I am enclosing in this letter a small pinch of sweet peas from a bunch that has been near her face and thought you might like to keep it. We are also sending you some of the ribbons of the wreaths which we could save, and that had not been too much spoilt by the rain. Photographs and whole report are also following.

I also send you the translation of Capt. Aureggio's speech, one of poor Betty;s grateful patients, and two letters from London she received a few days ago. All this will show you in what high esteem you dear beloved daughter was looked upon. She will never be forgotten by any of us. We have not only lost a devoted Sister, but a very great and very much loved friend. We are with you in your grief and we tender you and all your family our deepest sympathy.

Yours very sincere and much afflicted friend,

Lily Casalis

(Information about dr Casalis obtained from A History of Medicine in South Africa by Edmund H. Burrows, A.A. Balkema, 1958, p. 234, and from The Journal of the Medical Association of S.A. (B.M.A.) 9 May 1931, pp 294, 295). 


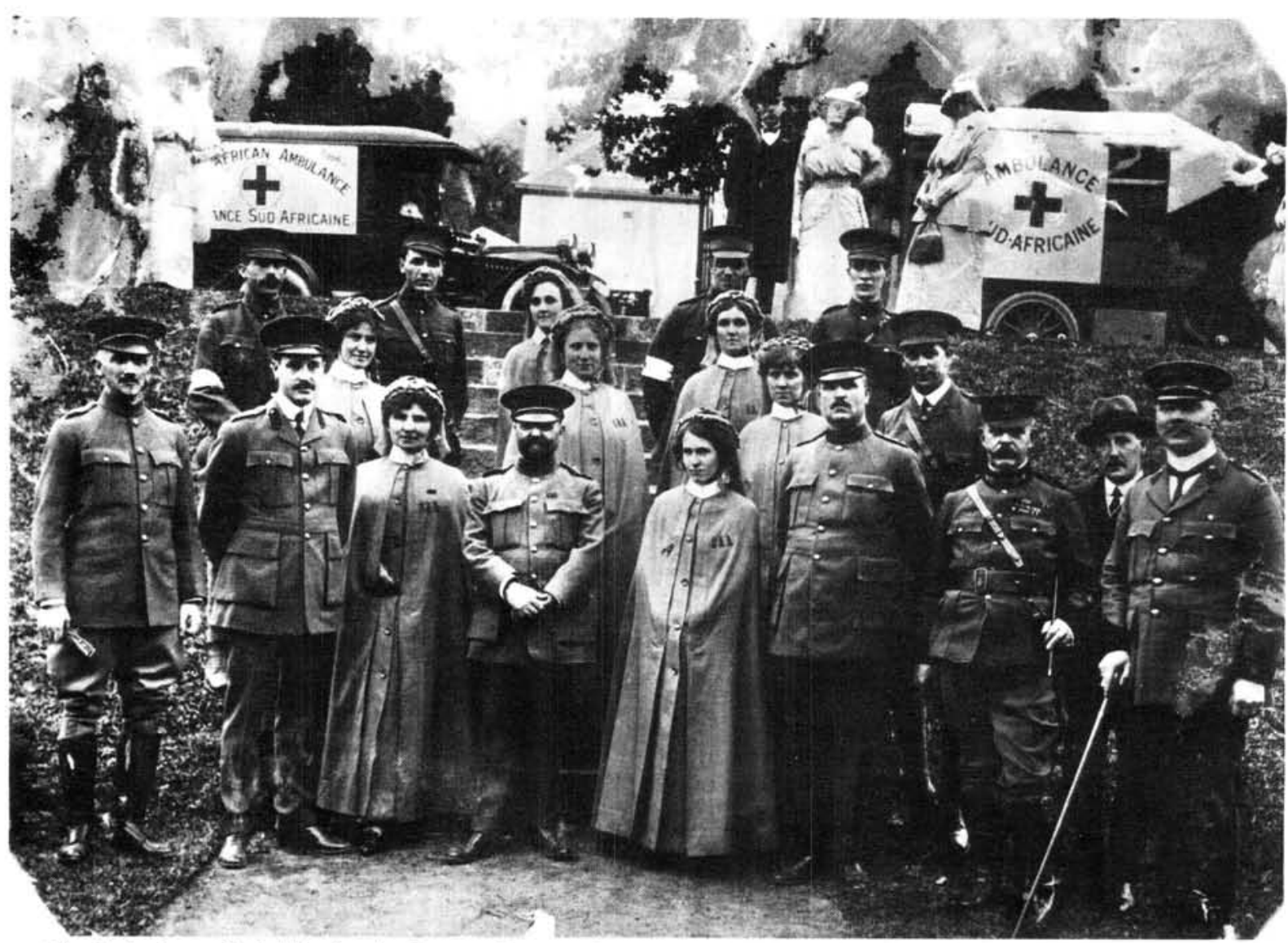

The Ambulance Sud-Africaine in Cannes, France. Centre front (with beard) dr Casalis; Betty Freund behind him

\section{The Ambulance Sud-Africana, by dr Casalis}

The following is an excerpt from a letter received from Lieut.-Col. Casalis, dated 8 May 1915, and published in the South African Medical Record of 12 June 1915:

We began to learn what waiting meant when we were in London. Alas, for the tedious and prolonged waits in official backrooms, to obtain a brief interview or merely a signature at foot of a document. It took us six weeks to get partially ready, six weeks of anxiety and toil to galvanize certain people into activity, to interest, here and there, a wealthy man in our great enterprise, then at last off to France and our good work. Here we thought it would surely be "plain sailing". Had we not heard that hospitals were badly needed, were we not expected, and did I not hold a valuable document which would open all doors to our energies? But no, we had overlooked the official mind. We had forgotten that the best intentions of Governments can be set at naught by an obtuse rond de cuir - who does not understand, in fact cannot understand, and will not budge until a charge of gun-powder is set alight under him.

But why recall all this? Why talk further about men and women who, out of sheer devilry, al- most wrecked our schemes? All that is now past, and our work prospers. We get plenty of it, and the results we achieve fill our hearts with pride and gratitude. Above all, we are a happy family, united and animated by the greatest love for our poor mutilated soldiers. Poor beggars! I thought I had seen something of misery already. I had been through the Boer War, but that was mere child's play, a "fleabite" compared to this Titanic struggle. Why, at Neuve Chapelle alone, our guns fired more ammunition than they did during the three years the struggle lasted in South Africa. Here, in two months, I have seen more surgery and operated on more cases than I did in the full period of the Boer War. And what surgery it is! Here is, for instance, a case recently arrived from Les Eparges, with an arm badly shattered by a piece of shell. It went clean through it above the elbow joint, leaving a gaping hole the size of a five franc piece. The bone was practically pulverized, the muscles, biceps, etc., protruding through a gash as large as the palm of one's hand, and yet the main vessels are untouched; most of the nerves also. Why not try the impossible, and save the mans' arm? In the attempt we have learned many things, forgotten new precepts, and remembered old ones, returning with reluctance some cherished treatment of our stu- 
dent days; in the end the poor fellow's arm was saved.

Who was it invented antiseptic baths for badly injured and infected limbs? I don't remember, but in all these cases it is the thing. If the wound is elsewhere on the trunk, go back to the old boric fomentations, apply them often, warm if possible and steadily. You will see wonders. The fever abates, also the pain; pus rapidly decreases and healthy granulations soon make their appearance. Asceptic dry dressings, you ask? Ah, yes; they were tried, are still being applied by our French friends, but they are a delusion and a snare. Why? Because in this war nothing is clean; it is the dirtiest, most villainous, and filthiest of wars. All is putrid, the ground one sleeps on, the clothes one wears, the bullets we fire or receive, and above all, the shells and shrapnel that tear one to pieces. It is water that is wanted for this awful dirt; plenty of it. Irrigate, therefore, and keep washing out the wounds, change your dressings continually; it will repay you tenfold. General Graäl, the other day, looking at our clean, healthy wounds, asked: "Have you already dressed these cases this morning?" No, the last dressings had been applied the night before; very little pus had soiled the bandages.

Try dry dressings before the wound is well cleaned and granulating. You will judge of the difference. But this is not all; we have learned another lesson. Always probe a wound. Never take for granted, because there is one hole of entry and another of exit, or because you are told the projectile has been recovered, that there is nothing left behind. Listen! On the 12th of last month a man was admitted into the Beau Rivage. He could walk, had been wounded through the muscles of the thigh by a bullet, so he thought; anyway, there was a tiny wound on one side and a large wound on the other. I concurred in the diagnosis. The small hole made by a high velocity bullet had evidently, in this case, left an aseptic wound. Aseptic, forsooth, what an error! There was not fever for a couple of days, no pain; then suddenly up went the temperature to $104^{\circ} \mathrm{F}$. The limb began to swell, hardened rapidly, assumed a bluish tint, and on the operating table we found a huge abscess, and in the stinking pus surging out, with the vicious appearance of a filthy torrent, small pieces of shrapnel, pieces of trousers and overcoat rolled out. Nothing could stay the imminent catastrophy at hand; twenty-four hours afterwards the man was blue all over, gasping for breath, an acute case of gaseous gangrene! Moral, open all wounds that look suspicious; open them wide, wash them, drain them, do all you can, but keep cleaning; that's the royal road to safety and health. There is no other.

Another fetish, which has passed away - the rubber tube - the drainage tube. Dear me! Whoever pretended that gauze could not drain?

When I was first asked to take charge of the surgery at the Continental Hospital here. I was surprised to see wounds bristling all over with huge drainage tubes, like a modern fortress with guns; yet no good was done. They were taken out regularly, boiled, irrigated; the pus went burrowing its way under muscles, tendons, and in many cases the limb was ultimately lost. Curiously enough, the infecting material in these cases is a low form of organism, its actions are slow, the temperature and pulse are rarely above the normal, but nothing seems to restrain a gradual but general infection of all the tissues.

I have never been a friend of the drainage-tube; to my mind, it only drains the immediate surroundings, creates round itself a sort of protective wall of feeble granulations, generally badly infected, and quite unable to protect from bacterial invasion the deeper tissues beyond. It has only one advantage; it is easily introduced and painless. I was therefore happy to drop it and revert once more to our old friend the "medicated gauze", introduced daily after a thorough curettage of the whole infected tissues. The results are wonderful, and the drainage tube has practically disappeared from our dressing wagons both here and at the Continental. This war should prove to be the revindication of antiseptic versus purely aseptic surgery. Both methods should, of course, go hand in hand, but if one was asked to choose, I would at present take up the old weapon. Many surgeons have yet to realize the advantage of a certain class of antiseptics. Mercury is nowhere, but peroxide of hydrogen, oxygenated water as the French call it, reigns supreme. We use a modified form specially provided and supplied to the Beau Rivage, and which goes by the name of hypochlorine.

Another shibboleth, gone by, is that you cannot obtain primary union of an infected area. I send you two photos, which prove the contrary. I shall never forget the amazed look of some members of the staff at the Continental, when, after cleaning and curetting an awful tear in the buttock of a man, reaching right down to the pelvic cavity, I boldly introduced at the upper portion a couple of silk-worm sutures. But it will never heal! they 
said. Well, you see the result in photo No. 2, which I enclose. The man is now allright. I had already tried the dodge in No. 1 case, and obtained satisfactory results, so I knew what I was about. Of course, it is always necessary to leave a good exit for drainage, but you may well imagine how this new form of treatment - I may say new - because I am not aware that anyone has yet done the thing before - greatly accelerates matters and brings about the closure of otherwise interminable fistulae. The practice is now a current one at the Beau Rivage, and I shall shortly publish a series of cases with photos to illustrate the technique followed. I could write pages on this and other cognate matters, on the vagaries of shrapnel and bullets, on the tolerance of the body to even large pieces of steel metal. One man has a good-sized fragment in his right lung, and, but for a little shortness of breath and occasional bleeding, does not appear to be the worse for it. I could tell you of amazing military surgery, which, coupled with official meddlesomeness, leads to awful surgical misdeeds, like what is called amputation en saucisson, or the clean chopping off legs and arms without flap formations and necessitating double operations later; but time fails me to-day. Let me only assure you once more that the S.A.A. is a wonderful and extraordinary experience to us all; more, that it is a success undreamed of, certainly a credit to our people, but better still, a great means of alleviating suffering and doing a little towards the great cause of justice and liberty. Never forget in the South, let the English never forget also, that in this war, if we come out on the right side, the French, by their tenacity, their valour, their unselfishness, have saved us from the Teutonic yoke; but of the "piou-piou", as the French soldier is called, I will one day write more. $\mathrm{He}$ is an epic in himself and a hero.

*The compiler and editor of the above article, Betty Hugo, was born in Bloemfontein in 1931, parents Judge-President CL Botha and Mina Freund (youngest sister of Betty Freund).

She obtained Drama Diplomas (English and Afrikaans) at Stellenbosch University in 1951 (under the late Robert Mohr and Marguerite de Villiers). Returned to University ten years later, obtained BA and BA Hons (English) at Stellenbosch in 1961 and 1963 respectively. Had done tour with NTO in 1954, and was also active throughout in amateur theatre in Stellenbosch (founder member of Libertas Theatre Club, still flourishing).

She was appointed as lecturer in the Dept of English Unisa in 1964; MA obtained in 1966; senior lecturer 1967; resigned 1969. Did freelance translation and theatre work (ie a film for Jans Rautenbach, a part for CAPAB 1971 and a lot of amateur theatre work as well); appointed to post in Dept of English at University of Pretoria 1972; senior post 1980; is still there in that capacity.

She is married to Prof. Leon Hugo (now Head of the Dept of English UNISA) and has published a collection of short stories with her husband (South of Capricorn, Academica, 1974) and is currently negotiating with de Jager-HAUM about collections of one-act plays. 